\title{
Theoretical Analysis Model of the Adoption of Reactive and Proactive Eco- Innovation Strategies: the Influence of Contextual Factors Internal and External to Organizations
}

\author{
Marlete Beatriz Maçaneiro ${ }^{\dagger}$ \\ Universidade Estadual do Centro-Oeste \\ Sieglinde Kindl da Cunha ${ }^{\Omega}$ \\ Universidade Positivo
}

\begin{abstract}
This article aims to provide research propositions of the relationship between internal and external contextual factors and strategies for reactive and proactive eco-innovation, defining the theoretical analysis model from these propositions. Therefore, this study is characterized as a theoretical essay, adopting the methodological procedure of literature review, through an analysis of national and international articles on the subject of eco-innovation strategy. As a result, the external and internal factors that affect the adoption of eco-innovation strategies were defined and propositions were made for their relationship. With this theoretical approach and the establishment of the factors, it was possible to design the theoretical model to analyze the impact of contextual factors on the adoption of eco-innovation strategies.
\end{abstract}

Keywords: Eco-innovation. Contextual factors. Environmental strategies. Reactive and proactive strategies.

${ }^{\dagger}$. Doctor in Business Administration from Universidade Federal do Paraná

Bond: Adjunct Professor at the Universidade

Estadual do Centro-Oeste

Address: Rua Augusto Gomes de Oliveira,

Guarapuava - PR - Brazil

E-mail: marlete.beatriz@yahoo.com.br

Phone: (042) 3621-1015

\footnotetext{
${ }^{\Omega}$ Doctor in Economy from the Economy Institute of UNICAMP

Bond: Full Professor at Universidade Positivo

Address: Rua Rui Arzua Pereira, Curitiba - PR - Brazil

E-mail: skcunha21@gmail.com

Phone: (41) 3317-3101
}

Editor's Note: This paper was accepted by Emerson Mainardes 


\section{INTRODUCTION}

$n$ the current economic context, in which organizations are developing their activities in a competitive manner, not only in the region where they are located, but globally, organizational change is necessary for the legitimacy and survival of businesses. When the defined strategies do not meet the speed and nature of the changes needed, or when organizational structures are complex, companies are forced to undergo radical changes, under penalty of being eliminated by the competition. In this context, environmental management is of strategic value, since it is characterized by gains in reduced resources, costs, productivity and competitiveness.

According to Porter and Linde (1995), organizations' competitiveness lies in the tradeoff between regulatory compliance and the earnings derived therefrom, which are often correlated, so that the achievement of one can lead to several other productivity gains. These authors emphasize that the paradigm of international competitiveness is based on innovation and continuous improvement, with no place for static efficiency or optimization within fixed limits. When properly designed, environmental standards can trigger innovation and fully pay off their compliance costs, leading to absolute advantages over other companies in foreign countries, which are not subject to similar regulations.

Nevertheless, Blackburn (2008) suggests that firms do not take into account the environmental management programs as a proactive business strategy, with a view to its competitiveness. This issue, in many cases, has connotation reactive at the pressures of the media, society and environmental regulation. When this occurs, companies regard environmental management as a risk (cost) that can damage their reputation, sales and business growth.

Other authors also corroborate this view, such as Foxon and Andersen (2009), Lustosa (1999), Nidumolu, Prahalad and Rangaswami (2009), Palmer and Salles Filho (1996) and Young et al. (2009). They point out that there is a belief by companies that costs of environmental management are high, resulting in reduced competitiveness. This issue is traditionally treated just like corporate social responsibility, and not as a proactive business strategy; i.e., reactive actions are taken.

Authors like Ansanelli (2011) argue around the question of how environmental policy can stimulate or be a determinant of innovation, being a boost to the generation of innovations and technological, economic and competitive opportunities. This requires a fundamental cultural change in companies, changing how they respond to environmental requirements. In 
this sense, managerial factors influence "[...] and may limit the kind and extent of technological changes that are likely or possible." (ASHFORD, 2000, p. 3). According to Hart (1995, p. 986), the evidence suggests that "[...] internal and external factors are crucial to competitive success", because considering these factors allows the definition of realistic proactive strategies. For Menguc, Auh and Ozanne (2010, p. 280), both factors "[...] are complementary and capture the extent of a firm's social performance and responsiveness."

Thus, this study is based on a review of the existing literature, which argues the need to combine technological innovation management with environmental protection issues, integrating internal and external factors to capture the essence of proactive eco-innovation strategy management. Over the years, eco-innovation management has been addressed by theorists from different countries and theoretical concepts. In some of them, the term used is "environmental innovation", while others use "eco-innovation" to refer to innovations for environmental purposes. In this study, the terms above are considered synonymous, but for reasons of uniformity throughout the work, only the term "eco-innovation" will be used, except in direct quotations from other authors. Furthermore, this paper is part of a larger study that aimed to examine various aspects of the relationship between contextual factors and the adoption of eco-innovation strategies.

Eco-innovations are defined as innovations with emphasis on sustainable development, resulting, during their entire life cycle, in the reduction of environmental risks, pollution and other negative impacts of resource usage, compared to existing alternatives (RENNINGS 2000; ARUNDEL; KEMP, 2009).

According to Arundel, Kemp and Parto (2003), eco-innovation is encouraged by several factors, including government regulations and subsidies, business opportunities for cleaner production and adoption of environmental ethics by companies in response to public pressure. The authors note that, until the late 80s, it became an integral part of the corporate strategy of many companies in developed countries, also spreading increasingly in developing countries. However, aspects involving eco-innovation are not yet known at all levels. Studies and ways to implement broader issues of management, that may consider actions on the entire context of an innovation system, are still under preparation.

Therefore, the purpose of this study is to present research propositions on the relationship between internal and external contextual factors and strategies for reactive and proactive eco-innovation. In addition, and as a result, this research also aims to develop a theoretical analysis model from these propositions. 
Authors such as Andersen (2010), Andrade (2004), Arundel and Kemp (2009) and Baumgarten (2008) argue the need to work the intersection between innovation and environmental management issues that are still permeated by theoretical uncertainties, methodological and political management. This characterizes this area as a scarcely explored field, especially in Brazil, but which has been gaining increasing attention in international literature, especially in the countries of the European Union and the United States (MAÇANEIRO; CUNHA, 2014; MAÇANEIRO; CUNHA; BALBINOT, 2013).

Thus, the literature analysis suggests that there is a lack of studies that simultaneously address the internal and external perspectives relative to a strategy for the environment and their interactive effects, placing the company in the social-environmental context. This is the purpose of this study, contributing to the definition of propositions on the relationship between contextual factors and the adoption of eco-innovation strategies, creating a theoretical model that can be analyzed in different contexts.

Additionally to this introduction, the paper consists of four more chapters. The second chapter deals with methodological considerations that underlie the study, followed by the third chapter, which presents the theoretical basis, presenting concepts, definitions and characteristics of eco-innovation strategies, as well as the adoption of reactive and proactive strategies by organizations. In the fourth chapter the propositions are presented, from contextual factors that are internal and external to organizations, translating them into proactive and reactive strategies. In the conclusion, we discuss the results of the study, with the definition of the theoretical analysis model, followed by suggestions for future research.

\section{METHODOLOGY}

Based on the goals, this study is characterized as a theoretical essay, adopting the procedure of reviewing national and international literature on the subject of eco-innovation strategy. A methodology based on exploratory and explanatory research in the context of the qualitative approach has also been adopted.

According to Taylor and Procter (2012), the literature review is an account of what has been published on a topic by scholars and researchers, not only as a descriptive list of the material available, or a set of summaries. In addition to expanding the knowledge on the topic, it should allow a critical assessment and identify areas of controversy in the literature, and formulate questions that need further research. 
It was exploratory because it is considered a matter on which there is little theoretical, methodological and empirical knowledge. According to Cervo and Bervian (2002, p. 69), "such studies aim to familiarize oneself with the phenomenon or obtain new perception of it and discover new ideas. Exploratory research performs accurate descriptions of the situation and aims to discover the relationships existing between its elements."

Therefore, the study was also outlined in the type of explanatory research, which aims "[...] to identify the factors that determine or contribute to the occurrence of a phenomenon. This is the kind of research that best expands the knowledge of reality, because it explains the reason of things" (GIL, 2007, p. 42).

The literature review was based on the analysis and assessment of national and international articles on the topic of eco-innovation and the adoption of strategies by organizations. Searches were conducted via Capes' Portal de Periódicos and Proquest webpages, having access to major periodicals and records of national and international events. The searched terms were: sustainability coupled with the term innovation, environmental innovation and eco-innovation. The period of research and analysis of the articles was between June 2011 and January 2012.

\section{THEORETICAL REFERENCES}

The innovation strategy is seen not in the sense of creation and application of complex and predictable mechanisms by organizations, but rather on creating effective conditions for their development. "Innovation is a matter of management, since there are choices to be made about sources and their arrangement and coordination" (TIDD; BESSANT; PAVITT, 2008, p. 100). Defining strategies provides organizations with the ability to predict or to be informed about issues that were previously unexplored by them. "A strategy is the pattern or plan that integrates the organization's major goals, policies, and action sequences into a cohesive whole" (QUINN, 2006, p. 29).

According to Hoskisson et al. (2009), the current ideas about strategy derive from the pioneering work of Alfred Chandler, published in 1962, followed by the study of Igor Ansoff, 1965. However, a classic book on the strategy process was published by Edmund Learned, C. Ronald Christensen, Kenneth Andrews and William Guth in 1965, at Harvard Business School.

These authors defined strategy as "the pattern of objectives, purposes or goals and major policies and plans for achieving these goals, stated in such a way as to define what businesses the company is in or should b ein and the kind of company it is or should be" (HOSKISSON et al., 2009, p. 10). 
From the first conception of strategy to the present day, a fierce debate has remained, with several schools, approaches and strategic theories being created. However, this article does not intend to discuss schools or strategic approaches, but to contribute to the development of eco-innovations in organizations. In this sense, two types of strategies related to eco-innovation are highlighted by theorists: reactive and proactive strategies.

Reactive strategies are defined by Buysse and Verbeke (2003, p. 454) as investments in those technologies end-of-pipe, which " [...] reflect a reactive posture to environmental issues, whereby limited resources are committed to solving environmental problems: product and manufacturing process improvements are made to conform to legal requirements." End-ofpipe technologies are solutions aimed only to control pollution that has already occurred, acting at the end of the production process, without any other substantial change in the life cycle of the product (BARBIERI, 2002; LUSTOSA, 2003). According to Hart (1995), these technologies rely on large capital investments, which make it expensive solutions, with costs of installation and operation.

Companies with a reactive strategy do not see environmental management as a priority, but invest only to comply with the regulations in force. Regulation is seen as a mere institutional constraint, and even as a threat, an additional cost, and not as an opportunity to improve management practices. Besides, the involvement of top management is only sporadic, where environmental actions are confined to areas that generate pollution. (BARBIERI, 2011; BUYSSE; VERBEKE, 2003)

In the case of proactive strategies, environmental strategies are defined as "pollution prevention" or "proactive", they are the so-called as cleaner production solutions. Are voluntary actions to reduce environmental impacts, which enable organizations to create competitive advantage by adopting eco-innovations technologies. (BUYSSE; VERBEKE, 2003; HART, 1995; MENGUC; AUH; OZANNE, 2010; SHARMA, 2000; SHARMA; PABLO; VREDENBURG, 1999). "The term cleaner production refers to a broader approach to environmental protection, because it considers all phases of the manufacturing process and the life cycle of the product, including its use in households and workplaces" (BARBIERI, 2011, p. 40).

Hart (1995, p. 993) states that "[...] a pollution-prevention strategy should facilitate lower costs, which, in turn, should result in enhanced cash flow and profitability for the firm." More specifically, Menguc, Auh and Ozanne (2010, p. 281) emphasize that 
A PES [proactive environmental strategies] aims to minimize emissions, effluents, and wastes. Central to a PES are continuous improvement methods that focus on well-defined environmental objectives rather than relying on expensive "end-ofpipe" capital investments to control emissions.

"Apart from the prevention and pollution control practices, the company seeks to take advantage of market opportunities and neutralize threats from environmental issues existing or that may occur in the future" (BARBIERI, 2011, p. 113). With this, companies build sustainable value chains, with the creation of environmentally friendly products and services. They focus on reducing consumption of non-renewable and renewable resources, extending from factories and offices to the value chain. They also start to understand the concerns of consumers and tend to check the sources of raw materials and distribution, in partnership with non-governmental organizations. (NIDUMOLU; PRAHALAD; RANGASWAMI, 2009). For Hart (1995), pollution prevention focuses on building new production and operations capacity, and can achieve significant reductions in costs and in expanding the capabilities of the company to a sustainable competitive advantage. However, Hart (1995, p. 998-999) also warns

[...] that competitive advantage must be created within a broader scope of social legitimacy. [...] A pollution-prevention strategy seeks to reduce emissions using continuous-improvement methods focused on well-defined environmental objectives rather than relying on expensive "end-of-pipe" capital investments to control emissions $[\ldots]$.

That is, companies acquire the skills required for knowing how renewable and nonrenewable resources affect the ecosystems of businesses and industries, combining business models, technologies and regulations in different industries. This ultimately reduces costs and even the creation of new sustainable business models, new ways of thinking involving distribution and capturing value for the customer, which will change the basis of competition. This is where changes occur to the existing paradigm concerning environmental protection, focusing on the adoption of eco-innovations (NIDUMOLU; PRAHALAD; RANGASWAMI, 2009). "Pollution prevention increases the company's productivity, as the reduction of pollutants at the source means resources saved, so you can produce more goods and services with fewer input" (BARBIERI, 2011, p. 110).

From proactive strategies, organizations tend to engage in concerns that transcend internal issues, including efforts towards consumer protection, pollution control, safety and quality of products, medical and social assistance, among other aspects (DONAIRE, 2007). However, there is no way to disregard the economic nature of these issues, which impact on the productivity of organizations, by the pressures from society and regulation. 


\section{ANALYSIS OF THE IMPACT OF CONTEXTUAL FACTORS ON THE ADOPTION OF STRATEGIES AND CONSTITUTION OF PROPOSITIONS}

The literature presents a number of factors that can affect the formulation and the type of eco-innovation strategy adopted by organizations, which play a fundamental role in this paper. The main factors that will be part of the theoretical model of this study are: 1) External factors: environmental regulation, government incentives to environment and innovation, reputation effects on the insertion context; 2) internal factors: support from senior management, skills and abilities of technological absorption, formalization of environmental issues. Thus, below is presented an analysis of the literature about internal and external contextual factors that impact eco-innovation strategies, defining the research propositions on the relationship of these factors with proactive and reactive strategies.

\subsection{FACTORS EXTERNAL TO ORGANIZATIONS}

Blackburn (2008) calls attention to the fact that many business owners do not see sustainability programs as essential to business success. Characterize this type of program as necessary at times to "polish the image" of the organization, but can be quickly discarded when the financial results fall. Also, realize the need only comply with the rules, in order to meet and comply with environmental legislation.

The environmental regulation is permeated by different mechanisms of legal rules in relation to environmental performance, called economic instruments. There are the traditional regulations of the "command and control", composed of fines and penalties, which affect costs and consumption, as well as common instruments such as taxation and subsidies. There is also less interventionist approaches, self-regulation by companies or industry sectors, acting as incentives for improved environmental management. (MOTTA; YOUNG, 1997; SCHMIDHEINY, 1992).

In Brazil, Motta and Young (1997) claim that government policies for environmental management have focused to economic instruments (royalties, tax offsets, water use and forest taxation), to generate revenue linked to the sector. Moreover, "[...] the policies, legislation and gaps in enforcement and other standards have created an institutional distrust, increased bureaucratic costs and introduced a high uncertainty in environmental rules." (MOTTA; YOUNG, 1997 p. 6).

These aspects provided a skepticism on the part of organizations and made them realize the environmental legislation as an aggregator of costs and risks to productivity. The prevailing view is that there is a dilemma arising from social benefits of rigorous 
environmental regulations and "[...] industry's private costs for prevention and cleanup costs that lead to higher prices and reduced competitiveness" (PORTER, van der LINDE, 1999, p 371, emphasis of the authors). With this vision, companies do not realize the recoverability of these investments, but that regulation increases costs and, consequently, lowers productivity (BARBIERI, 2011; DONAIRE, 2007; YOUNG et al., 2009).

These assumptions lead to the need to analyze the perception of industrial enterprises as the impact of environmental regulations on their strategies for eco-innovation, consider this regulation as cost (threat) to the business or strategic opportunity, resulting in reactive or proactive actions. Thus, we define the first proposition of the study:

P1: The perception of executives on environmental regulation is positively related to the adoption of reactive eco-innovation strategies.

Moreover, technological innovation is permeated by a context of production of cuttingedge science in research and development sectors within businesses. For this to occur, direct and indirect government influences in the productive sector are necessary. Companies that acquire economic incentives for their innovations can directly incorporate cutting edge technologies into products/services, making them more competitive, both domestically and internationally (KRUGLIANSKAS; MATIAS-PEREIRA, 2005). “[...] The institutional environment can also act in this selection process through legislation, subsidies, credits, loans and other instruments" (LUSTOSA, 2003, p. 165).

Policies to encourage private $R \& D$ efforts in companies allow technological strengthening and important changes in the "[...] behavior, towards more intensive strategies in own R\&D efforts and partnerships with universities and research institutes" (PACHECO, 2007, p. 11).

In Brazil, there was a recent development of a policy focused on Science, Technology and Innovation (ST\&I), which occurred from the late 90s. The theoretical milestone in this direction was the enactment of the Innovation Law, the Asset Law and the regulations of the National Fund for Scientific and Technological Development (FNDCT). Other policies were also important, such as the Informatics Law, which enabled further growth of the private productive sector in STI expenses in the country. These stimuli instruments are accompanied by demands for compensations, through private investment in $R \& D$ activities. Besides, there is the need to transfer resources to the sectorial funds derived from revenues of the companies 
that receive incentives, which subsequently return to the financing of innovation projects (MAÇANEIRO; CHEROBIM, 2011).

According to Barbieri (2011, p. 113), “[...] government support in form of financing and privileged rates, accelerated depreciation and other forms of economic incentives may be needed for a more broad diffusion of these new technologies". This enables decision making for adoption of pollution prevention through proactive strategies.

Therefore, it is considered that these laws/incentives have decisive influence on ecoinnovation strategies of private organizations, enabling greater effort towards environmental issues. This factor defines the second proposition of this study:

P2: The use of government incentives for innovation and environmental actions is positively related to the adoption of proactive eco-innovation strategies.

Not only is this a factor that impacts on the strategies, but according to Barbieri (2011, p. 113), “[...] the involvement of companies with environmental issues acquires strategic importance as it increases the interest of public opinion on environmental issues, as well as of groups interested in these problems: workers, consumers, investors and environmentalists. [...]". Factors such as consumer protection, product safety and quality, medical and social assistance and pressure by society, the media, environmental organizations, among others, are concerns that go beyond the internal issues of organizations and that impact the formalization of eco-innovation strategies. The pressure can be exerted “[...] by many groups, from neighbouring populations of an industrial enterprise that threatens the environment, through parliamentarians, civil society organizations - in which the activities of environmental nongovernmental organizations (NGOs) are very important [...]" (LUSTOSA, 2003, p. 165).

Companies need to react to these local pressures and market conditions with research and production skills, to meet these demands. The ability to anticipate and react to these changes taking place in their business context makes them gain cost-effectiveness and profitability. "Ignoring these trends has cost many companies a large amount of money and embarrassments to its corporate image" (DONAIRE, 2007, p. 18). These impacting factors are considered the "reputational effects" and not respecting their signals represents subsequent operating/tax costs. That is, "taking into account public opinion, in turn, can be seen as a constraint (cost) or as a technological opportunity" (ROMEIRO; SALLES FILHO, 1996, p. 105) by the companies. 
Therefore, the "reputational effects" from the local context are considered as major drivers of environmentally proactive strategies, where companies seek publicity in the press and media.

[...] are instrumental to shaping public opinion in favor of (or against) a company. [...] Firms with a reactive environmental strategy do not view environmental management as an important function, implying that they are likely to perceive the claims of environmental NGOs and the media as illegitimate [...] (BUYSSE; VERBEKE, 2003 , p. 461).

In the study by Lau and Ragothaman (1997), the company's reputation was regarded as second in order of importance among the driving forces for better environmental performance of companies. Consumers, in general, are increasingly aware of the environmental impact of products and require improvement of the environmental performance of products by the industry. On the one hand, conscious consumers may be willing to pay a higher value for environmentally friendly products, but on the other hand, they may also exert negative pressures, boycotting products from companies with poor environmental reputation (BUYSSE; VERBEKE, 2003).

Therefore, these pressures of the companies' operation context with environmentally friendly products and processes greatly impact the way organizations develop and build their eco-innovation strategies, which defines the third proposition of the study:

P3: The perception of the "reputation effect" is positively related to the adoption of proactive eco-innovation strategies.

\subsection{FACTORS INTERNAL TO ORGANIZATIONS}

The proactive eco-innovation strategies require a shared long-term vision among stakeholders, but mainly it is necessary to have the support of the organization's senior management (HART, 1995). "The leaders of the organization may have different levels of commitment to the environmental issues of the company, and this can affect their environmental strategies" (SOUZA, 2004, p. 247-248). For Donaire (1996, p. 51), “[...] the most important and significant aspect to be considered is the political willingness of senior management to transform the ecological issue into a fundamental company principle [...].”

Lau and Ragothaman (1997) found in their study that the initiatives of top management are considered as third in order of importance of the driving forces for improved environmental performance of companies. To Menguc, Auh and Ozanne (2010), senior management is responsible for initiating and defending proactive environmental strategies, 
such as deliberate top-down processes in organizational levels. Therefore, this suggests the following proposition:

P4: The support of the top management for environmental issues is positively related to the adoption of proactive eco-innovation strategies.

The literature also points to another factor, which is the technological competency, related to performing $R \& D$ internally and with the absorptive capacity of an organization. According to Cohen and Levinthal (1990) absorptive capacity is the ability of a company to recognize the value of new - exploitation of external knowledge - assimilate it and apply it for commercial purposes. It is critical to its ability to innovate and invest in R\&D. At the same time, $\mathrm{R} \& \mathrm{D}$ not only generates new knowledge, but also contributes to the absorption capacity of the company.

According to Ashford (2000) and Carrillo-Hermosilla, Gonzalez and Könnölä (2009), in the case of eco-innovations, the impacting factors of technological competence are related to:

a) Improving the base skills of the company through education and training of its operators, workers and managers for the development of eco-innovations;

b) Capacity for innovation determined by technological maturity and flexibility of a given product or production line, as well as the installation and adjustment conditions for adoption of new clean technologies;

c) Ability to engage in the collaboration and information flows about opportunities inherent to environmental issues, through formal analysis of technological options;

d) Building relationships and strategic partnerships through the informal transfer of knowledge from suppliers, customers, trade associations, unions, workers and other companies, including other sources of information.

Economists define three determinant factors for R\&D intensity: demand; appropriability (ability to exploit profit opportunities); and conditions of technological opportunity (cost to achieve a technical breakthrough in a particular industry). The absorption capacity will mediate the effects of these economic determinants (COHEN; LEVINTHAL, 1990). In this sense, Freeman (1996, p. 38) points out that "The transition to renewable energy systems in the 21 st century will not be possible [...] without some far greater R\&D commitment in the public and private sector as well as procurrent policies." The environmental issue "is, rather, 
an action that takes place in a context of uncertainty about the results; partially dependent on the skills acquired by the company (cumulative); and partly determined by the nature of the technology involved" (ROMEIRO; SALLES FILHO, 1996, p. 95). Accordingly, the fifth proposition considers that:

P5: Greater technological competence is positively related to the adoption of proactive eco-innovation strategies.

A corporate culture favorable to change and active in environmental protection and innovation, with the implementation of appropriate models for eco-innovation management has favorable characteristics for environmental performance. This requires a high degree of leadership by managers linked to environmental protection and the implementation of an environmental management system (EMS) (CARRILLO-HERMOSILLA; GONZALEZ; KÖNNÖLÄ, 2009).

The adoption of quality standards such as ISO 14000 can be seen as an environmentally proactive measure. However, Buysse and Verbeke (2003, p. 455) warn that these standards, in most cases, require only that companies operate in accordance with government regulations. "In addition, these meta standards may be used for window-dressing purposes by firms with only a superficial commitment to environmental protection."

Therefore, a set of effective attitudes by organizations can constitute a construct that would cover a favorable environmental characterization. These environmental protection actions can be considered as impactful on proactive eco-innovation strategies, composing the sixth proposition of the study:

P6: Environmental protection actions formalized in the corporate structure are positively related to the adoption of proactive eco-innovation strategies.

Furthermore, the position in the production chain is a factor that can impact the performance of actions taken by businesses that are environmentally friendly. According to Carrillo-Hermosilla, Gonzalez and Könnölä (2009), companies that are at the end of the production process are more likely to meet the pressure of environmentally responsible final consumers. Companies under pressure of such consumers consider social legitimacy and reputation as an important factor in their strategic considerations (MENGUC; AUH; OZANNE, 2010). In this sense, the position in the supply chain can influence the relationship between the "reputational effects" and the adoption of strategies. 
These same companies tend to have in their structure an environmental formalization greater than the other companies of their industry. The transition to a more proactive environmental management, influenced by conscious consumers, is especially important in industries that have close contact with end consumers (BUYSSE; VERBEKE, 2003). Therefore, it also influences the environmental formalization, and the innovation can lead to development of more environmentally friendly solutions for the integration of the company's business, influencing their technological competence.

Because of these aspects, the position in the supply chain can be a moderator construct and here it is part of the seventh proposition raised:

P7: The position of the company in the supply chain positively moderates the relationship between internal and external contextual factors in the adoption of ecoinnovation strategies.

Besides this moderator construct, other (intervening) variables may interfere with relationships identified by the propositions, such as organizational size, age, capital origin and market of operation. These intervening variables are part of the theoretical model developed and presented in the next section.

Authors mention that there is a connection between the size of the company and its ecoinnovation behavior (CARRILLO-HERMOSILLA; GONZALEZ; KÖNNÖLÄ, 2009; YOUNG et al., 2009). The size of the company can be reflected in the perceived importance of the pressure factors to adopt environmental issues, such as smaller companies that give less importance to international customers, suppliers and competitors, than large companies (BUYSSE; VERBEKE, 2003). “[...] As company size increases, the greater the degree of complexity of its operations and, consequently, the need for an organized and structured management" (PASSOS, 2003, p. 104)

Carrillo-Hermosilla, Gonzalez and Könnölä (2009) also point out that the age of the company, related to its technological competence, is an important factor because older organizations are prone to organizational inertia.

Another factor identified as important for environmental management is the source of capital stock of the company (CARRILLO-HERMOSILLA; GONZALEZ; KÖNNÖLÄ, 2009; PASSOS, 2003). "It is assumed that foreign-capital companies have a more proactive stance toward the environment through exposure to a more mature public opinion on environmental issues, as well as more stringent laws" (PASSOS, 2003, p. 104). That is, 
Multinational enterprises are also more exposed to pressures from international customers, suppliers, and rivals (often subsidiaries of multinational enterprises). They are also more likely to use international standards and other voluntary agreements as a benchmark for their own environmental strategy. (BUYSSE; VERBEKE, 2003, p. 462)

Therefore, foreign-capital companies appear to be more concerned about environmental issues, pressure from foreign shareholders, adopting environmental standards of the controlling company, as well as demanding foreign consumers (LUSTOSA, 2003).

Besides, national companies with international businesses also tend to adopt ecoinnovations and perceive the environment as business opportunities in a higher degree than those who work in the domestic market (YOUNG et al., 2009). One of the contributing factors for this to occur is that consumers in international markets demand better quality products and services that are environmentally friendly (MILES; COVIN, 2000). Another factor is that companies competing in international markets need to transpose the policies of that country, which forces them to develop eco-innovation strategies (CARRILLOHERMOSILLA; GONZALEZ; KÖNNÖLÄ, 2009; DONAIRE, 2007).

Due to all these factors, contextual changes external to organizations tend to intensify the need to develop internal mechanisms that are consolidated and flexible at the same time. They should allow "[...] not only a quick adjustment to changes that may be occurring in their environment, but also enable a strategic posture in anticipation of changes that will arise" (DONAIRE, 2007, p. 25).

In this sense, building strong ties inside and outside the industry, related to these impacting agents/factors, and the acquisition of more knowledge about environmental activities can increase the sensitivity of the organization to environmental concerns. Additionally, it can allow a comparison of companies' environmental activities, with that of competitors in the market (MENGUC; AUH; OZANNE, 2010).

\section{FINAL REMARKS AND CONTRIBUTIONS OF THE STUDY}

This theoretical paper aimed to provide propositions to the relationship between contextual factors and strategies for reactive and proactive eco-innovation, creating the definition of the theoretical model of analysis from these propositions.

In the literature, studies related to the topic of interest of this paper assume that environmental strategies can be defined as proactive (opportunity) and reactive (threat and cost) (ARAGÓN-CORREA, 1998; BARBIERI, 2011; BUYSSE; VERBEKE, 2003; MENGUC; AUH; OZANNE, 2010; SHARMA, 2000; SHARMA; PABLO; VREDENBURG, 
1999). Authors also postulate that internal and external contextual factors contribute decisively to the definition of environmental strategies for organizations, but they relate differently. In the external context, the influence of environmental regulation is crucial for the adoption of environmental strategies (BARBIERI, 2011; DONAIRE, 2007; MOTTA; YOUNG, 1997; YOUNG et al., 2009). Besides regulation, the literature also highlights the key role that government incentives for innovation and environmental actions have in defining strategies (BARBIERI, 2011; KRUGLIANSKAS; MATIAS-PEREIRA, 2005; LUSTOSA, 2003; PACHECO, 2007); and the "reputational effects" arising from the local context, which are also considered as drivers of environmentally-proactive strategies (BARBIERI, 2011; BUYSSE; VERBEKE, 2003; DONAIRE, 2007; LAU; RAGOTHAMAN, 1997; LUSTOSA, 2003; ROMEIRO; SALLES FILHO, 1996). On the other hand, in the national context, authors place the support of senior management as crucial in the adoption of proactive strategies (HART, 1995; LAU; RAGOTHAMAN, 1997; MENGUC; AUH; OZANNE, 2010; SOUZA, 2004), and the literature also indicates technological competence as an important driver of proactive strategies (ASHFORD, 2000; CARRILLOHERMOSILLA; GONZALEZ; KÖNNÖLÄ， 2009; COHEN; LEVINTHAL， 1990; ROMEIRO; SALLES FILHO, 1996). In this context, a corporate culture which is formalized in terms of environmental protection is also considered by the authors as important for adopting proactive strategies (BUYSSE; VERBEKE, 2003; CARRILLO-HERMOSILLA; GONZALEZ; KÖNNÖLÄ, 2009). Other authors consider that the position of companies in the supply chain impacts their environmental strategic decisions (BUYSSE; VERBEKE, 2003; CARRILLO-HERMOSILLA; GONZALEZ; KÖNNÖLÄ, 2009; MENGUC; AUH; OZANNE, 2010).

Regarding eco-innovation strategies, previous studies on this topic made a great contribution, such as studies by: Aragón-Correa (1998); Arundel and Kemp (2009); Buysse and Verbeke (2003); Donaire (1996); Hart (1995); Lau and Ragothaman (1997); Menguc, Auh and Ozanne (2010); Sharma (2000); Sharma, Aragón-Correa and Rueda-Manzanares (2007); Souza (2004). However, the analysis found that there is a lack of studies that simultaneously address the internal and external perspectives related to an eco-innovation strategy and their interactive effects, placing the company in the environmental context. Thus, this study can serve as a guide for conducting future research in this area.

In the analysis of external and internal factors that affect the adoption of eco-innovation strategies and propositions were presented for their relationship. Initially, external factors 
were analyzed, starting with environmental regulations. It is emphasized that it should be focused on orientation to innovation and companies should see the regulations the potential for improving productivity and competitiveness. Besides the regulations, other external contextual factors were also considered as impactful on eco-innovation strategies and, consequently, on the environmental performance of organizations. These factors are related to the government incentives for environmental innovation, the effects of reputation in the operation context, that impact on the company image. They must be managed jointly and interactively between the barriers and drivers in the adoption of environmentally friendly practices and technologies. That is for companies to maintain a real image favorable to environmental concerns, and not just see natural resources as inputs and the environment as a waste deposit of production actions.

Internal factors that lead to eco-innovation management were also analyzed. In general, it can be inferred that these factors are related mainly to the support of the company's senior management, which becomes crucial for decision making in this field. But also the ones related to the skills and capabilities of technological absorption of companies, which provide the necessary conditions for this adoption. On the other hand, the more the organization formalizes environmental issues in its internal context, the more its culture and features are so modified, with the internalization of environmental preservation.

Moreover, it was also considered important to analyze the company's position in the production chain, as a factor that can impact the achievement of environmentally favorable or unfavorable actions. Companies with direct sales to consumers may be more likely to comply with the environmentally responsible pressure. However, it should also be considered in this respect that the pressure of large buyers in the supply chain can also cause suppliers to adopt environmental initiatives.

Furthermore, certain intervening variables were also considered, which may affect the relationship between contextual factors and strategies for eco-innovation, such as the organization's size, age, origin of capital and market of operation.

From this survey and from the definitions above, it was possible to conceive the theoretical analysis model, as shown in Figure 1. This model considers the existence of a relationship between contextual factors of the organization, with its definitions of ecoinnovation strategies being controlled by the position that the company occupies in the supply chain, as well as other intervening variables. 


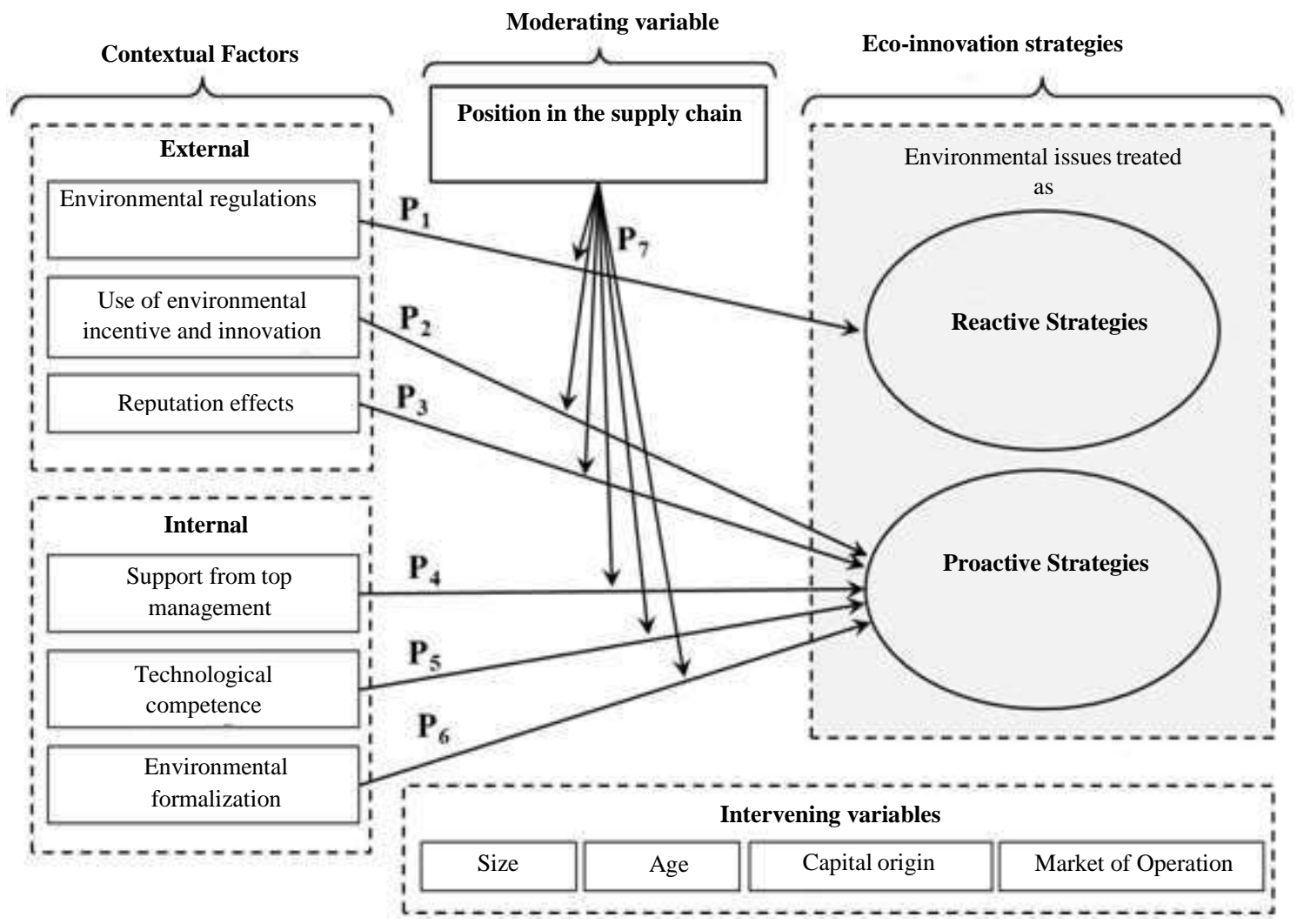

Figure 1 - Theoretical Analysis Model

With this model, this study may contribute as to how to analyze the processes of ecoinnovation in different contexts and industry types. Considering all aspects covered in this paper, in terms of contribution to the advancement of knowledge in the area of eco-innovation strategies, the definition of propositions on the relationship between the adoption of reactive and proactive strategies may be considered. But the definition of internal and external factors that influence this adoption also was an important contribution.

Moreover, it can provide information on eco-innovation management, on its drivers and effects, allowing detailed analyses of specific studies, which is a gap in the literature. In this sense, a framework was established for setting long-term goals in company policies, presenting the factors and their implications in companies' eco-innovation strategies.

Future studies may conduct empirical research from these propositions and contextual factors in order to prove or disprove them, to obtain a greater knowledge on the topic of ecoinnovation. Or they can develop other researches dealing in a greater degree with the factors considered in this study, as well as other contextual factors.

More specifically, future research studies can be conducted in different areas from the propositions and from the contextual factors defined herein so as to compare eco-innovation 
behavior in different sectors of activity. Therefore, this study can serve as a guide for future research in this area, both for longitudinal studies as well as for quantitative and qualitative studies. Qualitative studies could further deepen the topic discussed herein, in order to verify aspects that are not possible to analyze, depending on the distance between the researcher and the object of study in quantitative studies.

In addition thereto, other topics on eco-innovation can be complemented in future studies, which were possible to extract from the survey of the theoretical basis, but which were not the topic of this article. It is important, for the topic of eco-innovation, to examine, in a deeper context, which eco-innovation strategies are being adopted by companies and the impacts of these strategies on their social, environmental and economic performance.

Another major topic in the context of eco-innovation is the eco-entrepreneurship, that is, the creation of technology-based ecological companies. This topic is relevant since it portrays exactly the inclusion of eco-innovation in these organizations, since, for being defined as highly innovative, allying itself with environmental management, many factors that contribute to the studies in the area can be analyzed.

The analysis of information sources and relations of technology transfer in the context of eco-innovation is also important. Questioning the types of knowledge that are transferred, identifying critical gaps in the knowledge infrastructure and what sources of knowledge are most useful for this topic. Studies in this area of technology transfer could also check appropriability conditions in the eco-innovation field, the issue of maintaining the secrecy of innovation or licensing to other organizations, among other aspects.

The subject of the definition of government policies is also of paramount importance to eco-innovation, addressing the styles of environmental policy that can lead to innovation. Comparative studies in this context are critical, bringing different effects and policy regimes on environmental innovation, also asking companies whether existing policies are effective incentives. Broader issues in this policy line could also involve the analysis of national innovation systems regarding the environment, also dealing with an international empirical analysis, analyzing the specific features of eco-innovation in different systems and the environmental innovative capacity of different countries.

These areas are still unexplored in terms of research on the topic of eco-innovation, which is considered critical for future research. It is important to note that studies should 
consider how environmental issues are understood, but also what is known and what is being done for the "greening" of the industry, market and society in general.

\section{REFERENCES}

ANDERSEN, M. M. On the faces and phases of eco-innovation - on the dynamics of the greening of the economy. In: DRUID SUMMER CONFERENCE, 16-18 jun. 2010, London. Opening up innovation: strategy, organization and technology, London, Imperial College London Business School, 2010.

ANDRADE, T. H. N. de. Inovação tecnológica e meio ambiente: a construção de novos enfoques. Ambiente \& Sociedade, Campinas, v. 7, n. 1, p. 89-106, jan./jun. 2004.

ANSANELLI, S. L. Exigências ambientais europeias: novos desafios competitivos para o complexo eletrônico brasileiro. Revista Brasileira de Inovação, v. 10, n. 1, p. 129-160, 2011.

ARAGÓN-CORREA, J. A. Strategic proactivity and firm approach to the natural environment. Academy of Management Journal, v. 41, n. 5, p. 556-567, out. 1998.

ARUNDEL, A.; KEMP, R. Measuring eco-innovation. UNU-MERIT, Working Paper Series, 2009. Disponível em: <http://www.merit.unu.edu/publications/wppdf/2009/wp2009017.pdf>. Acesso em: 16 jun. 2010.

ARUNDEL, A.; KEMP, R.; PARTO, S. Indicators for environmental innovation: what and how to measure. In: ANNANDALE, D.; PHILLIMORE, J.; MARINOVA, D. (eds.). International handbook on environment and technology management. Cheltenham: Edward Elgar, 2003. p. 324-339.

ASHFORD, N. A. An innovation-based strategy for a sustainable environment. In: HEMMELSKAMP, J.; RENNINGS, K.; LEONE, F. (Eds.). Innovation-oriented environmental regulation: theoretical approach and empirical analysis. ZEW Economic Studies. New York: Springer Verlag, Heidelberg, 2000. p. 67-107. Disponível em: <http://18.7.29.232/bitstream/handle/1721.1/1590/Potsdam.pdf?sequence=1> Acesso em: 29 jan. 2012.

BARBIERI, J. C. Desenvolvimento e meio ambiente: as estratégias de mudanças da Agenda 21. 5. ed. Petrópolis: Vozes, 2002.

BARBIERI, J. C. Gestão ambiental empresarial: conceitos, modelos e instrumentos. 3. ed. São Paulo: Saraiva, 2011.

BAUMGARTEN, M. Ciência, tecnologia e desenvolvimento: redes e inovação social. Parcerias Estratégicas, Brasília, n. 26, p. 102-123, jun. 2008.

BLACKBURN, W. R. The sustainability handbook. Washington: Environmental Law Institute, 2008.

BUYSSE, K.; VERBEKE, A. Proactive environmental strategies: a stakeholder management perspective. Strategic Management Journal, v. 24, n. 5, p. 453-470, maio 2003. 
CARRILLO-HERMOSILLA, J.; GONZÁLEZ, P. del R.; KÖNNÖLÄ, T. Barriers to ecoinnovation. Eco-innovation: when sustainability and competitiveness shake hands. New York: Palgrave Macmillan, 2009. cap. 3, p. 28-50.

CERVO, A. L.; BERVIAN, P. A. Metodologia científica. 5. ed. São Paulo: Prentice Hall, 2002.

COHEN, W. M.; LEVINTHAL, D. A. Absorptive capacity: a new perspective on learning and innovation. Administrative Science Quarterly, v. 35, n. 1, p. 128-152, 1990.

DONAIRE, D. Gestão ambiental na empresa. 2. ed. São Paulo: Atlas, 2007.

DONAIRE, D. A internalização da gestão ambiental na empresa. Revista de Administração, São Paulo v. 31, n. 1, p. 44-51, jan./mar. 1996.

FOXON, T.; ANDERSEN, M. M. The greening of innovation systems for eco-innovation towards an evolutionary climate mitigation policy. In: DRUID SUMMER CONFERENCE, 2009, Copenhagen (NOR). Anais... Copenhagen: Druid, 2009.

FREEMAN, C. The greening of technology and models of innovation. Technological forecasting and social change, v. 53, n. 1, p. 27-39, sep. 1996.

GIL, A. C. Como elaborar projetos de pesquisa. 4. ed. São Paulo: Atlas, 2007.

HART, S. A natural-resource-based view of the firm. The Academy of Management Review, v. 20, n. 4, p. 986-1014, out. 1995.

HOSKISSON, R. E. et al. Estratégia competitiva. 2. ed. São Paulo: Cengage Learning, 2009.

KRUGLIANSKAS, I.; MATIAS-PEREIRA, J. Um enfoque sobre a Lei de Inovação Tecnológica do Brasil. Revista de Administração Pública, Rio de Janeiro, v. 39, n. 5, p. 1011-1029, set./out. 2005.

LAU, R. S. M.; RAGOTHAMAN, S. Strategic issues of environmental management. South Dakota Business Review, v. 56, n. 2, p. 1-7, 1997.

LUSTOSA, M. C. J. Inovação e meio ambiente no enfoque evolucionista: o caso das empresas paulistas. In: ENCONTRO NACIONAL DE ECONOMIA (ANPEC), 37., 1999, Belém (PA). Anais..., Belém, 1999. p. 1177-1194.

LUSTOSA, M. C. J. Industrialização, meio ambiente, inovação e competitividade. In: MAY, P. H.; LUSTOSA, M. C. J.; VINHA, V. da (Org.). Economia do meio ambiente: teoria e prática. Rio de Janeiro: Elsevier, 2003.

MAÇANEIRO, M. B.; CHEROBIM, A. P. M. S. Fontes de financiamento à inovação: incentivos e óbices às micro e pequenas empresas: estudo de casos múltiplos no estado do Paraná. Organizações \& Sociedade, Salvador, v. 18, n. 56, p. 57-75, jan./mar., 2011.

MAÇANEIRO, M. B.; CUNHA, S. K. DA; Contextual Factors as Drivers of Eco-innovation Strategies: The Definition of an Organizational Taxonomy in the Brazilian Cellulose, Paper, and Paper Products Industry. In: AZEVEDO, S. G. et al. (Eds.). Eco-Innovation and the 
Development of Business Models: Lessons from Experience and New Frontiers in Theory and Practice. New York: Springer, 2014. p. 137-162.

MAÇANEIRO, M. B.; CUNHA, S. K. DA; BALBINOT, Z. Drivers of the adoption of ecoinnovations in the pulp, paper, and paper products industry in Brazil. Latin American

Business Review, v. 14, p. 179-208, 2013. doi: 10.1080/10978526.2013.833465

MENGUC, B.; AUH, S.; OZANNE, L. The interactive effect of internal and external factors on a proactive environmental strategy and its influence on a firm's performance. Journal of Business Ethics, v. 94, p. 279-298, 2010.

MILES, M. P.; COVIN, J. G. Environmental marketing: a source of reputational, competitive, and financial advantage. Journal of Business Ethics, v. 23, n. 3, p. 299-311, fev. 2000.

MOTTA, R. S.; YOUNG, C. E. F. (Coord.). Instrumentos econômicos para a gestão ambiental no Brasil. Rio de Janeiro, dez. 1997. Disponível em:

$<$ http://www.coletivobraganca.com.br/download/instrumentos_econ\%C3\%B4micos_de_gest \%C3\%A3o_ambiental_no_brasil.pdf> Acesso em: 24 jan. 2012.

NIDUMOLU, R.; PRAHALAD, C. K.; RANGASWAMI, M. R. Why sustainability is now the key driver of innovation. Harvard Business Review, n. 87, p. 56-64, set. 2009.

PACHECO, C. A. As reformas da política nacional de ciência, tecnologia e inovação no Brasil: (1999-2002). Santiago (CHI): Comissão Econômica para América Latina e Caribe (CEPAL), 2007. Disponível em:

<www.eclac.org/iyd/noticias/paginas/5/31425/carlosamericop.pdf> Acesso em: 02 out. 2011.

PASSOS, L. A. N. Gestão ambiental e competitividade: um estudo do setor químico brasileiro. 2003. 166 f. Dissertação (Mestrado em Gestão de Negócios) - Universidade Estadual de Maringá, Londrina, 2003.

PORTER, M.; van der LINDE, C. Toward a new conception of the environmentcompetitiveness relationship. Journal of Economic Perspective, v. 9, n. 4, p. 97-118, 1995.

PORTER, M.; van der LINDE, C. Verde e competitivo: acabando com o impasse. In: PORTER, M. E. Competição = on competition: estratégias competitivas essenciais. Rio de Janeiro: Campus, 1999. p. 371-397.

QUINN, J. B. Estratégias para mudança. In: MINTZBERG, H. et al. O processo da estratégia: conceitos, contextos e casos selecionados. 4. ed. Porto Alegre: Bookman, 2006. p. 29-34.

RENNINGS, K. Redefining innovation - eco-innovation research and the contribution from ecological economics. Ecological Economics, v. 32, p. 319-332, 2000.

ROMEIRO, A. R.; SALLES FILHO, S. Dinâmica de inovações sob restrição ambiental. In: ROMEIRO, A. R.; REYDON, B. P.; LEONARDI, M. L. A. Economia do meio ambiente: teoria, políticas e a gestão de espaços regionais. Campinas: UNICAMP, 1996.

SCHMIDHEINY, S. Mudando o rumo: uma perspectiva empresarial global sobre desenvolvimento e meio ambiente. Rio de Janeiro: Ed. da FGV, 1992. 
SHARMA, S. Managerial interpretations and organizational context as predictors of corporate choice of environmental strategy. Academy of Management Journal, Briarcliff Manor, v. 43, p. 681-697, ago. 2000.

SHARMA, S.; ARAGÓN-CORREA, J. A.; RUEDA-MANZANARES, A. The contingent influence of organizational capabilities on proactive environmental strategy in the service sector: an analysis of North American and European Ski Resorts. Canadian Journal of Administrative Sciences, v. 24, n. 4, p. 268-283, dez. 2007.

SHARMA, S.; PABLO, A. L.; VREDENBURG, H. Corporate environmental responsiveness strategies: the importance of issue interpretation and organizational context. The Journal of Applied Behavioral Science, v. 35, n. 1, p. 87-108, mar. 1999.

SOUZA, R. S. de. Fatores de formação e desenvolvimento das estratégias ambientais nas empresas. 2004. 283 f. Tese (Doutorado em Administração) - Universidade Federal do Rio Grande do Sul (UFRGS), Porto Alegre (RS), 2004.

TAYLOR, D.; PROCTER, M. The literature review: a few tips on conducting it. Disponível em: <http://www.writing.utoronto.ca/images/stories/Documents/literature-review.pdf >. Acesso em: 06 jan. 2012.

TIDD, J.; BESSANT, J.; PAVITT, K. Gestão da inovação. 3. ed. Porto Alegre: Bookman, 2008.

YOUNG, C. E. F. et al. Determinants of environmental innovation in the Brazilian industry. In: CONGRESO DE LA ASOCIACIÓN LATINOAMERICANA Y DEL CARIBE DE ECONOMISTAS AMBIENTALES Y DE RECURSOS NATURALES, 4., 2009, Heredia (CR). Anais... Heredia: UNA (Universidad Nacional Costa Rica), 2009. Disponível em: <http://www.ie.ufrj.br/gema/pdfs/DETERMINANTS\%20OF\%20ENVIRONMENTAL\%20I NNOVATION\%20IN\%20THE\%20BRAZILIAN\%20INDUSTRY.pdf>Acesso em: 27 jun. 2011. 